Original Research

\title{
Isolation of Novel Toluene Degrading Bacteria from Waste Water Treatment Plants and Determination of their Toluene Tolerance and other Biotechnological Potential
}

\author{
Nilgün Poyraz* \\ Department of Biology, Faculty of Science and Humanities, Kütahya Dumlupınar University, Kütahya, Turkey
}

Received: 27 March 2020

Accepted: 6 June 2020

\begin{abstract}
Toluene is an aromatic hydrocarbon and spreads to the environment by the release of petroleum products, agricultural and industrial activities and toluene can cause serious social and health problems. Since the removal in toluene is considered an important environmental issue, there is an increasing interest of toluene biodegradation. In this comprehensive study, novel toluene degrading bacteria were isolated and identified both from municipal and industrial wastewater treatment plants. Isolates' toluene tolerance, enzyme production, benzene, ethyl benzene, xylene and phenol degradation potentials and biofilm formation were examined. Totally 109 bacterial isolates were obtained and most of them were determined as belong to Stenotrophomonas, Acinetobacter and Pseudomonas species.

Isolates' toluene tolerance, enzyme production, benzene, ethyl benzene, xylene and phenol degradation potentials and biofilm formation were examined. Most of isolates showed lipase, DNase and protease activity. Most of isolates showed growth in $300 \mathrm{mg} / \mathrm{l}^{-1}$ concentrations of benzene, ethyl benzene, xylene and phenol. Strains E4T16, 3AT2 and 3ET5 showed maximum growth in high toluene concentrations and also strain E4T16 showed growth up to $2100 \mathrm{mg} / 1^{-1}$ toluene. Examination of biofilm formation at different toluene concentrations at the end of the 96 hours incubation revealed that strains E4T16, 4ET21 and 3ET5 had highly biofilm production potential. In conclusion, these bacteria and results could be considered as a powerful new approach for the removal of hydrocarbons from wastewater.
\end{abstract}

Keywords: toluene, biodegradation, biofilm, enzyme, wastewater

*e-mail: nilgun.kavak@dpu.edu.tr 


\section{Introduction}

Toluene is an aromatic hydrocarbon, also is a natural component of petroleum and coal and is an important component of gasoline. It's IUPAC name is Methylbenzene [1,2]. Toluene is produced industrially in the production of various chemicals and also as a solvent. The major factors in the spread of toluene to the environment are the release of petroleum products, agricultural and industrial activities such as herbicides, pesticides, production paints, thinners, cigarette, polymers, automobile and car sprays and paintings [3-6].

Toluene can cause serious social and health problems [7]. It is moderately toxic when inhaled [8]. Continuous exposure to toluene may show mutagenic effects on cells [9]. Toluene is a well-known human neurotoxin and can cause leukoencephalopathy and also is known as carcinogens. It is also a threat to drinking water [7, $10]$.

For these reasons, the removal of toluene has become an important environmental issue. So, there is an increasing interest for utilizing microorganisms such as bacteria for removal of various aromatic compounds from the environment. Biodegradation with bacteria may play an important role in the reduction of such compounds. This technique is considered to be an effective technology for the treatment of pollution [11, 12].

Bacteria and fungi have developed several interesting pathways for toluene degradation. Under aerobic conditions, oxygen is used directly as a substrate and generally catechol and derivatives act as central metabolites. In the absence of oxygen, anaerobic toluene gradients carry out a unique reaction which adds fumarate to toluene [7]. Examples of toluenedegrading aerobic bacteria include genera such as Pseudomonas [13], Acinetobacter and Rhodococcus [14] and Bacillus [15]. Anaerobic degradation of toluene has been observed in denitrifying strains such as in some Thauera aromatica strains [16].

The aim of this study was to isolate and identify novel toluene-degrading bacteria from waste water treatment plants, and determination of their toluene tolerance with modified method and also other potential biotechnological properties of them such as enzyme production, other substances' degradation and biofilm formation. This information can serve to support further development, design and operation of new processes.

\section{Materials and Methods}

\section{Sample Collection}

Wastewater samples were taken from fat/sand removal unit, primary clarifiers unit, activated sludge, secondary clarifiers and return activated sludge pump units of a municipal wastewater treatment plant and an industrial wastewater treatment plant for 4 times in a year. All samples were obtained manually, placed in labelled plastic bottles and quickly transported to the laboratory.

\section{Determination of $\mathrm{BOD}_{5}$ and $\mathrm{pH}$ Values of Samples}

$\mathrm{BOD}_{5}$ values of the samples were measured manometrically (Oxitop) and $\mathrm{pH}$ was measured with $\mathrm{pH}$ meter (Mettler Toledo).

\section{Isolation of Toluene Degrading Bacteria}

Mineral salt (MS) medium was used to cultivate toluene degrading microorganisms from the samples. Mineral salt media includes; $\mathrm{K}_{2} \mathrm{HPO}_{4} 2.75 \mathrm{~g}, \mathrm{KH}_{2} \mathrm{PO}_{4}$ $2.25 \mathrm{~g},\left(\mathrm{NH}_{4}\right)_{2} \mathrm{SO}_{4} 1.0 \mathrm{~g}, \mathrm{MgCl}_{2} \cdot 6 \mathrm{H}_{2} \mathrm{O} 0.2 \mathrm{~g}, \mathrm{NaCI}$ $0.1 \mathrm{~g}, \mathrm{FeCI}_{3} .6 \mathrm{H}_{2} \mathrm{O} 0.02 \mathrm{~g}, \mathrm{CaCI}_{2} 0.01 \mathrm{~g}$ per liter distilled water.1 $\mathrm{ml}$ of each sample was taken separately and inoculated to liquid media. For toluene degradation, $3 \mathrm{mM}$ toluene was added as the sole carbon and energy sources. At the end of 7 days incubation at $37^{\circ} \mathrm{C}$, $150 \mathrm{rpm}, \mathrm{MS}$ solid media were prepared with toluene and $15 \mathrm{~g} / \mathrm{l}^{-1}$ agar and spread plate method was applied. The growing colonies were taken into pure culture and were kept at $-85^{\circ} \mathrm{C}$ in $20 \%$ glycerol stocks [17].

\section{Nucleic Acid Extraction from Isolates}

For extraction, Cifuentes et al., 2000; Nogales et al., 1999 and Singka et al., 2012 protocols were modified [18-20]. 200 milliliter of each sample was used for nucleic acid extraction. Samples were filtered through a $0.22-\mu \mathrm{m}$ pore size GV filter (Millipore). $0.5 \mathrm{~mm}$ glass beads in equal volume and extraction buffer $(100 \mathrm{mM}$ Tris- HCl, $100 \mathrm{mM}$ EDTA $\mathrm{pH}$ 8.0) were mixed. Then, lysozyme $\left(3 \mathrm{mg} \mathrm{mL}^{-1}\right)$, and Proteinase $\mathrm{K}\left(150 \mathrm{mg} \mathrm{mL}^{-1}\right)$ were added and incubated at $37{ }^{\circ} \mathrm{C}$ for 15 minutes. After these steps, $10 \%$ sodium dodecyl sulfate added $0.7 \mathrm{M} \mathrm{NaCl}$ and $10 \% \mathrm{CTAB}$ (Cetyltrimethyl-ammonium bromide) solution were added and vortexed. Then, nucleic acid extraction and purification were performed using phenol-chloroform-isoamyl alcohol (25:24:1) and chloroform-isoamyl alcohol (24:1) followed by ethanol precipitation. After the ethanol was removed by pipette, the pellet was dried at room temperature and resuspended with $50 \mu \mathrm{l}$ of diethylpyrrocarbonate (DEPC) water, and kept at $-85^{\circ} \mathrm{C} .0 .5 \mu \mathrm{l}$ of samples were pippetted to NanoDrop ND-1000 Spectrophotometer for detection of DNA concentrations. A 260/280 ratio of $\sim 1.8$ is generally accepted as "pure" for DNA. Other values show that a sample is contaminated by residual phenol, guanidine, or other extraction reagents.

\section{S rRNA Gene Targeted PCR Analysis}

PCR reactions were set up using Bacteria specific primers from the qualified DNAs. For the PCR reaction, 
27F (5'AGAGTTTGATCATGGCTCAG-3') for Bacteria was used as the forward primer, and $1492 \mathrm{R}$ (5'-GGTTACCTTGTTACGACTT3') was used as the reverse primer. Amplification was applied in $25 \mu 1$ PCR reaction mixture containing $22 \mu \mathrm{l}$ of $1 \mathrm{X}$ master mix which was prepared from 2X Master Mix (Biolabs OneTaq ${ }^{\circledR}$ Quick-Load ${ }^{\circledR} 2 \mathrm{X}$ Master Mix (M0486S)), 0.4 $\mu \mathrm{M}$ forward primer, $0.4 \mu \mathrm{M}$ reverse primer and $1 \mu \mathrm{l}$ template. PCR was performed in Techne TC-5000 Thermal Cycler at programme: a cycle of $94^{\circ} \mathrm{C}$ for $3 \mathrm{~min}$, 30 cycles of $94^{\circ} \mathrm{C}$ for $15 \mathrm{~s}, 55^{\circ} \mathrm{C}$ for $30 \mathrm{~s}$, and $72^{\circ} \mathrm{C}$ for $2 \mathrm{~min}$; plus an extension step of $7 \mathrm{~min}$ at $72^{\circ} \mathrm{C}$ [21].

\section{Amplified Ribosomal DNA Restriction Analysis (ARDRA)}

Hinf I enzyme was used for restriction analysis of PCR products obtained for 16S rRNA gene. For each reaction $1 \mu \mathrm{l} 5 \mathrm{U}$ enzyme (Biolabs), $10 \mu \mathrm{l}$ PCR product, $2 \mu \mathrm{l}$ restriction enzyme buffer (Biolabs) and $7 \mu \mathrm{l}$ DNase-RNase-free ultra-pure distilled water (Gibco) (total volume of $20 \mu \mathrm{l}$ ) were used. The mixture was incubated overnight at $37^{\circ} \mathrm{C}$ for restriction. For analysis, samples were loaded on a $2 \%$ agarose gel for 4 hours in 1X TBE (Tris-Boric acid-EDTA) buffer [22].

\section{DNA Sequence Analysis}

Different profiles were determined by ARDRA and were purified. Then sequencing reactions were set up separately using primers $27 \mathrm{~F}$ and $1492 \mathrm{R}$. Then $16 \mathrm{~S}$ rRNA gene sequences were compared with reference sequences at NCBI (http://www.ncbi.nlm.nih.gov) by using BLAST. Finally, representative sequences were determined and stored in GenBank with the accession numbers by using Sequin system.

Phylogenetic analysis was performed with these sequences and sequences from analysis were added to the tree using MEGA X. [23-25].

\section{Determination of the Toluene Monooxygenase Gene}

PCR reaction was established using primary subunit targeted primers of toluene monooxygenase gene. RMOF (5' TCTC(A/C/G)AGCAT(C/T)CAGAC (A/C/G)GACG-3') was used as the forward primer and RMOR (5'-TT(G/T)TCGATGAT(C/G/T)AC(A/G) TCCCA-3') was used as the reverse primer to establish PCR reaction. Amplification was applied in $25 \mu \mathrm{l} \mathrm{PCR}$ reaction mixture as before. PCR was performed at programme: a cycle of $94^{\circ} \mathrm{C}$ for $3 \mathrm{~min}, 30$ cycles of $94^{\circ} \mathrm{C}$ for $15 \mathrm{~s}, 53^{\circ} \mathrm{C}$ for $1 \mathrm{~min}$, and $72^{\circ} \mathrm{C}$ for $1 \mathrm{~min}$; plus an extension step of $10 \mathrm{~min}$ at $72^{\circ} \mathrm{C}$ [26].

\section{Benzene, Ethyl Benzene, Xylene and Phenol Degradation Potential of Isolates}

For evaluation degradation potential of other substances, modified method was tried [17]. Mineral salt (MS) medium was used and $3 \mathrm{mM}$ benzene, ethyl benzene, xylene and phenol was added separately to medium for each isolates. Then after three days incubation time, growth rate determined for each bacteria.

\section{Simple Screening for Enzyme Activities of Isolates}

Amylase, DNase (DNA), lipase on trybuthyrin and protease activities were tested at $37^{\circ} \mathrm{C}$. Prepoured plates were inoculated with bacteria. To avoid any interference from nearby colonies, only one isolate was inoculated onto each plate as a line form. For amylase activity the bacterial strains were inoculated media supplemented with $0.25 \%$ of starch. After incubation the zone of clearance was observed by adding Gram's iodine as detecting agent. Isolates were inoculated for protease production on milk nutrient medium. The zone of clearance was observed around the colonies indicated the proteolytic activity of that isolates [27]. For lipase, bacterial isolates were inoculated on tributyrin agar medium. After incubation development of a clear halo zone around the colony indicated lipase activity [28]. DNase Test Agar (Himedia) was used to differentiate between microorganisms based on their ability to produce the enzyme deoxyribonuclease (DNase). DNase producing organisms exhibited clear zone around growth against green background.

\section{Toluene Tolerance and Biofilm Production of Isolates}

Eight bacteria were then selected for the toluene degradation tests and allowed to grow in different toluene concentrations (300-600-900-1200-1500-1800$\left.2100 \mathrm{mg} / \mathrm{L}^{-1}\right)$ in 96-well microtiter plates. $150 \mu \mathrm{L}$ Minimal Salt medium in different toluene concentrations was inoculated with $50 \mu \mathrm{L}$ of culture which was McFarland 0.5 standard was provided. Tolerance and growth capacity was measured in O.D.(Optical Density) $600 \mathrm{~nm}$ at $24 \mathrm{~h}$ interval for $96 \mathrm{~h} \mathrm{[29].}$

Biofilm formation was assessed using same 96-well microtiter plates. After end of the 96 hours incubation, the wells washed three times with $200 \mu \mathrm{L}$ sterile PBS (Phosphate buffer saline) to remove suspended cells, dried at room temperature, and the amounts of forming biofilms were quantified using crystal violet method. Briefly, the wells were stained with $150 \mu \mathrm{L} /$ well $1 \%$ (w/v) crystal violet aqueous solution for $30 \mathrm{~min}$. Microtiter plates were placed in shaking for $30 \mathrm{~min}$. After removing the stain, the wells were washed three times by $200 \mu \mathrm{L}$ PBS and air dried. Finally, $200 \mu \mathrm{L}$ ethanol-acetone $(80: 20 \mathrm{v} / \mathrm{v})$ was added to each well and the absorbance measured at $590 \mathrm{~nm}$ wavelength [30, 31].

\section{Results and Discussion}

Experimental planning aimed to determine the potential of biodegradation because this is a subject of 
great interest in wastewater treatment. Biodegradation is an extremely ecological method, as it usually involves the breakdown of organic compounds by microorganisms into more cell biomass and less complex compounds and water. Especially hydrocarbon contamination in soil and water is still a major concern and considered as a serious environmental issue to various natural habitats.

Thus, the discovery of new species capable of more efficient biodegradation can bring great innovation to this field. In addition, biological treatment methods have less environmental impact, eco-friendly and are less costly than other methods, have greater capacity to remove organic pollutants $[32,33]$.

BTEX (benzene, toluene, ethylbenzene and xylene) are simple aromatic compounds and that are highly toxic. Many chemical and physical methods can be used for degradation and breakup into nontoxic products. But, use of microorganism is considered to be the best suitable way for the degradation of BTEX $[6,34$, 35]. Use of microorganisms and their enzymes for degradation can overcome the difficulties with other conventional methods.

Growth of bacteria in the presence of aromatic compounds shows their bioremediation ability of contaminated sites. Studies on biodegradation of toluene have been reported worldwide. However, biodegradation studies under aerobic conditions are lesser than anaerobic ones [36]. So, the present study aimed the identification of toluene degrading bacteria and determination of BTEX-degrading and biofilmforming potentials of bacteria which was developed in wastewater.

The $\mathrm{pH}$ and $\mathrm{BOD}_{5}$ measurement results of the samples were given in Tables 1 and 2. High rates of $\mathrm{BOD}_{5}$ values were obtained from industrial waste water treatment plant. $\mathrm{pH}$ values were average 7-8 in both plants, but it could be seen slightly higher in municipal waste water treatment plant.

Morphologically different and distinct a total of 48 isolates were determined from toluene medium from municipal wastewater treatment plant. A total of 61 isolates were isolated from industrial wastewater treatment plant. After isolation, DNA extraction was applied and DNA concentrations were measured as a minimum 55.8 ng per microliter, maximum 183.7 ng per microliter and average concentration value approximately 50-60 ng per microliter for templates. 260/280 ratios were measured nearly 1.8 . Then extracts were used as PCR templates. Approximately 1500 base pairs of bacterial 16S rRNA fragments were amplified from PCR analysis for isolates. Isolates were grouped with ARDRA. 8 different profiles of 16S rRNA products were detected. These representative profiles were sequenced. Sequences were compared with reference sequences at NCBI using BLAST. Most of the isolates were determined as belong to Stenotrophomonas species Acinetobacter baumanni and Pseudomanas species. Their accesion numbers and closest relatives were shown in Table 3 . In addition, their status in the phylogenetic tree was Fig. 1.

Toluene biodegradation has been reported and reviewed by numerous studies with different strain and culture condition in laboratory experimentation. When the studies on toluene degradation are examined, Pseudomonas and Bacillus species were generally isolated and identified [37-39]. Specifically, Pseudomonas putida and Pseudomonas aeroginosa species have been described in many studies. In our study, microorganisms was isolated from the toluene medium which was containing $300 \mathrm{mg} /$ liter toluene and their number was quite high. Toluene degrading species

Table 1. $\mathrm{BOD}_{5}$ measurement results of waste water treatment plants.

\begin{tabular}{|c|c|c|c|c|c|c|c|c|}
\hline & \multicolumn{2}{|c|}{$\begin{array}{c}\text { BOD mg/L } \\
\text { June 2015 }\end{array}$} & \multicolumn{2}{c|}{$\begin{array}{c}\text { BOD mg/L } \\
\text { October 2015 }\end{array}$} & \multicolumn{2}{c|}{$\begin{array}{c}\text { BOD mg/L } \\
\text { January 2016 }\end{array}$} & \multicolumn{2}{c|}{$\begin{array}{c}\text { BOD mg/L } \\
\text { April 2016 }\end{array}$} \\
\hline SAMPLES & $\begin{array}{c}\text { Municipal } \\
\text { waste water } \\
\text { treatment } \\
\text { plant }\end{array}$ & $\begin{array}{c}\text { Industrial } \\
\text { waste water } \\
\text { treatment } \\
\text { plant }\end{array}$ & $\begin{array}{c}\text { Municipal } \\
\text { waste water } \\
\text { treatment } \\
\text { plant }\end{array}$ & $\begin{array}{c}\text { Industrial } \\
\text { waste water } \\
\text { treatment } \\
\text { plant }\end{array}$ & $\begin{array}{c}\text { Municipal } \\
\text { waste water } \\
\text { treatment } \\
\text { plant }\end{array}$ & $\begin{array}{c}\text { Industrial } \\
\text { waste water } \\
\text { treatment } \\
\text { plant }\end{array}$ & $\begin{array}{c}\text { Municipal } \\
\text { waste water } \\
\text { treatment } \\
\text { plant }\end{array}$ & $\begin{array}{c}\text { Industrial } \\
\text { waste water } \\
\text { treatment } \\
\text { plant }\end{array}$ \\
\hline $\begin{array}{c}\text { Fat/Sand } \\
\text { Removal } \\
\text { Unit }\end{array}$ & 420 & 1000 & 500 & 900 & 340 & 900 & 380 & 1000 \\
\hline $\begin{array}{c}\text { Primary } \\
\text { Clarifiers } \\
\text { Unit }\end{array}$ & 60 & 840 & 360 & 1000 & 200 & 1000 & 380 & 1000 \\
\hline $\begin{array}{c}\text { Activated } \\
\text { Sludge Unit }\end{array}$ & 920 & 1000 & 1000 & 180 & 1000 & 180 & 1000 & 820 \\
\hline $\begin{array}{c}\text { Return-Acti- } \\
\text { vated Sludge } \\
\text { Pump }\end{array}$ & 820 & 980 & 1000 & 1000 & 1000 & 1000 & 960 & 1000 \\
\hline $\begin{array}{c}\text { Secondary } \\
\text { Clarifiers } \\
\text { Unit }\end{array}$ & 60 & 160 & 100 & 120 & 40 & 120 & 40 & 280 \\
\hline
\end{tabular}


Table 2. $\mathrm{pH}$ values of waste water treatment plants.

\begin{tabular}{|c|c|c|c|c|c|c|c|c|}
\hline & \multicolumn{2}{|c|}{ JH } & \multicolumn{2}{c|}{$\mathrm{pH}$} & \multicolumn{2}{c|}{$\mathrm{pH}$} \\
June 2015 & \multicolumn{2}{c|}{ October 2015 } & \multicolumn{2}{c|}{$\begin{array}{c}\mathrm{pH} \\
\text { January 2016 }\end{array}$} \\
\hline SAMPLES & $\begin{array}{c}\text { Municipal } \\
\text { waste water } \\
\text { treatment } \\
\text { plant }\end{array}$ & $\begin{array}{c}\text { Industrial } \\
\text { waste water } \\
\text { treatment } \\
\text { plant }\end{array}$ & $\begin{array}{c}\text { Municipal } \\
\text { waste water } \\
\text { treatment } \\
\text { plant }\end{array}$ & $\begin{array}{c}\text { Industrial } \\
\text { waste water } \\
\text { treatment } \\
\text { plant }\end{array}$ & $\begin{array}{c}\text { Municipal } \\
\text { waste water } \\
\text { treatment } \\
\text { plant }\end{array}$ & $\begin{array}{c}\text { Industrial } \\
\text { waste water } \\
\text { treatment } \\
\text { plant }\end{array}$ & $\begin{array}{c}\text { Municipal } \\
\text { waste water } \\
\text { treatment } \\
\text { plant }\end{array}$ & $\begin{array}{c}\text { Industrial } \\
\text { waste water } \\
\text { treatment } \\
\text { plant }\end{array}$ \\
\hline $\begin{array}{c}\text { Fat/Sand } \\
\text { Removal } \\
\text { Unit }\end{array}$ & 7.81 & 5.4 & 8.06 & 6.79 & 8.12 & 7.24 & 7.56 & 6.69 \\
\hline $\begin{array}{c}\text { Primary } \\
\text { Clarifiers } \\
\text { Unit }\end{array}$ & 8.19 & 6.8 & 8.03 & 6.67 & 8.32 & 6.92 & 7.77 & 6.75 \\
\hline $\begin{array}{c}\text { Activated } \\
\text { Sludge Unit }\end{array}$ & 7.49 & 7.1 & 7.46 & 7.33 & 7.21 & 7.33 & 7.25 & 7.39 \\
\hline $\begin{array}{c}\text { Return } \\
\text {-Activated } \\
\text { Sludge Pump }\end{array}$ & 7.27 & 7.1 & 7.37 & 7.43 & 7.13 & 7.65 & 7.16 & 7.46 \\
\hline $\begin{array}{c}\text { Secondary } \\
\text { Clarifiers } \\
\text { Unit }\end{array}$ & 7.01 & 8.04 & 7.66 & 7.74 & 7.32 & 7.72 & 7.56 & 7.60 \\
\hline
\end{tabular}

were identified as Stenotrophomonas acidaminiphila, Acinetobacter baumannii, Pseudomonas balearica, Pseudomonas otitidis, Streptococcus mitis and Stenotrophomonas maltophila. Many studies had been done on Stenotrophomonas maltophila and the number of studies on Stenotrophomonas acidaminiphila is extremely low. [40, 41]. Another species which makes toluene degradation was Pseudomonas balearica. Pseudomonas balearica was identified as a naphthalene degrader [42, 43]. In another study, it was isolated from biological wastes as oil degraders [44]. One of the species that degrades toluene was Pseudomonas

Table 3. Isolates, their accession numbers and their closest matches in GenBank.

\begin{tabular}{|c|c|c|c|c|}
\hline $\begin{array}{l}\text { Isolate } \\
\text { number }\end{array}$ & Species & $\begin{array}{l}\text { Accesion Number } \\
\text { (GenBank) Number }\end{array}$ & Closest Relative in Gene Bank & Similarity \% \\
\hline E5T32 & $\begin{array}{c}\text { Stenotrophomonas sp. strain E5T32 } \\
\text { 16S ribosomal RNA gene, partial } \\
\text { sequence }\end{array}$ & KX682240 & $\begin{array}{l}\text { Stenotrophomonas sp. strain JJ63 16S } \\
\text { ribosomal RNA gene, partial sequence } \\
\text { (KU375545.1) }\end{array}$ & $1161 / 1177(99 \%)$ \\
\hline E4T16 & $\begin{array}{c}\text { Pseudomonas balearica strain } \\
\text { E4T16 } 16 \text { S ribosomal RNA gene, } \\
\text { partial sequence }\end{array}$ & KX682241 & $\begin{array}{l}\text { Pseudomonas balearica DSM 6083, com- } \\
\text { plete genome (CP007511.1) }\end{array}$ & 1337/1341(99\%) \\
\hline $4 \mathrm{ET} 21$ & $\begin{array}{l}\text { Stenotrophomonas acidaminiphila } \\
\text { strain } 4 E T 2116 \text { ribosomal RNA } \\
\text { gene, partial sequence }\end{array}$ & KX682242 & $\begin{array}{c}\text { Stenotrophomonas acidaminiphila partial } \\
\text { 16S rRNA gene, strain Marseille-P2028 } \\
\text { (LT223687.1) }\end{array}$ & $575 / 588(98 \%)$ \\
\hline 4ET29 & $\begin{array}{l}\text { Stenotrophomonas acidaminiphila } \\
\text { strain } 4 E T 2916 \text { ribosomal RNA } \\
\text { gene, partial sequence }\end{array}$ & KX682243 & $\begin{array}{c}\text { Stenotrophomonas acidaminiphila strain } \\
\text { KP2 16S ribosomal RNA gene, partial } \\
\text { sequence (KU850955.1) }\end{array}$ & $435 / 445(98 \%)$ \\
\hline 3AT1 & $\begin{array}{l}\text { Stenotrophomonas acidaminiphila } \\
\text { strain } 3 A T 116 S \text { ribosomal RNA } \\
\text { gene, partial sequence }\end{array}$ & KX682244 & $\begin{array}{l}\text { Stenotrophomonas acidaminiphila strain } \\
\text { SR50-5 } 16 \text { S ribosomal RNA gene, partial } \\
\text { sequence (KF279369.1) }\end{array}$ & $1275 / 1280(99 \%)$ \\
\hline 3АT24 & $\begin{array}{l}\text { Acinetobacter baumannii strain } \\
3 A T 2416 S \text { ribosomal } R N A \text { gene, } \\
\text { partial sequence }\end{array}$ & KX682245 & $\begin{array}{c}\text { Acinetobacter baumannii OIFC189 clone } \\
106106426450616 \text { S ribosomal RNA gene, } \\
\text { partial sequence (JN668944.1) }\end{array}$ & $684 / 695(98 \%)$ \\
\hline 3ET4 & $\begin{array}{l}\text { Pseudomonas otitidis strain } 3 E T 4 \\
16 S \text { ribosomal RNA gene, partial } \\
\text { sequence }\end{array}$ & KX682246 & $\begin{array}{l}\text { Pseudomonas otitidis gene for } 16 S \\
\text { ribosomal RNA, partial sequence, } \\
\text { strain: } 81 f(A B 698739.1)\end{array}$ & $1264 / 1280(99 \%)$ \\
\hline 3ET5 & $\begin{array}{l}\text { Streptococcus mitis strain } 3 E T 5 \\
16 S \text { ribosomal RNA gene, partial } \\
\text { sequence }\end{array}$ & KX682247 & $\begin{array}{c}\text { Streptococcus mitis strain KCOM } 1350 \\
\text { (= ChDC B183), complete genome } \\
\text { (CP012646.1) }\end{array}$ & $1248 / 1263(99 \%)$ \\
\hline
\end{tabular}




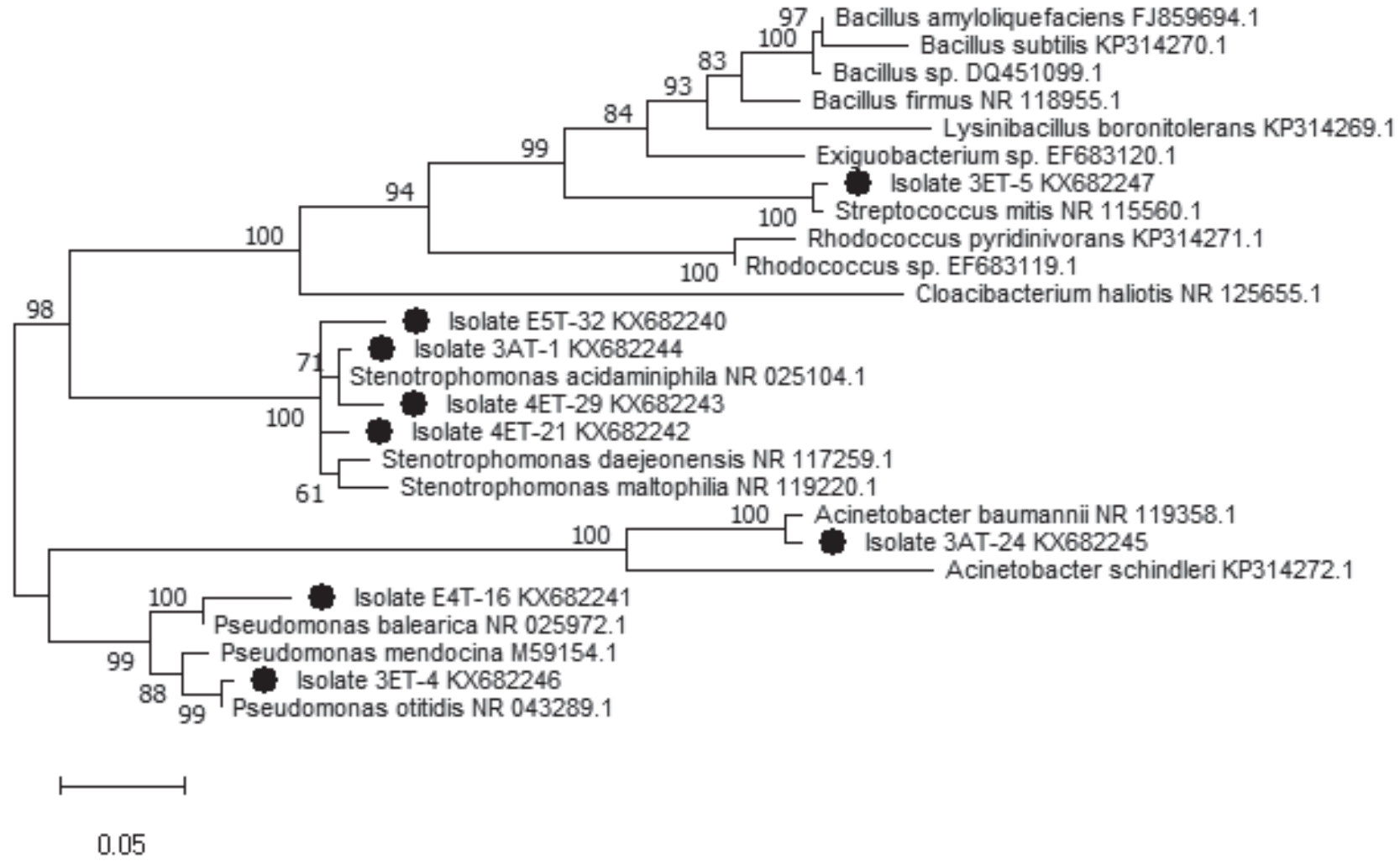

Fig. 1. Phylogenetic tree based on $16 \mathrm{~S}$ rRNA gene sequences from isolates belonging to bacteria (indicated by black circles) was constructed by maximum likelihood. The horizontal scale bar represents the number of substitutions per site.

otitidis. The number of studies related to this species is quite low. In a study on biosurfactant production, it was isolated and thought to have bioremediation potential [45]. Up to now several studies have identified many bacteria that degraded toluene (Table 6) [33, 46-51]. But, as a result, when compared with Table 6 , in our study new species that degraded toluene were identified.

The maximum O.D. (Optical Density) results indicates the maximum growth of those bacteria in different toluene concentrations. Fig. 2. showed maximum growth efficiency of identified strains with increased toluene concentrations in 24 hours. From Figs 3, 4, 5 it was found out that, 3ET4 (Pseudomonas

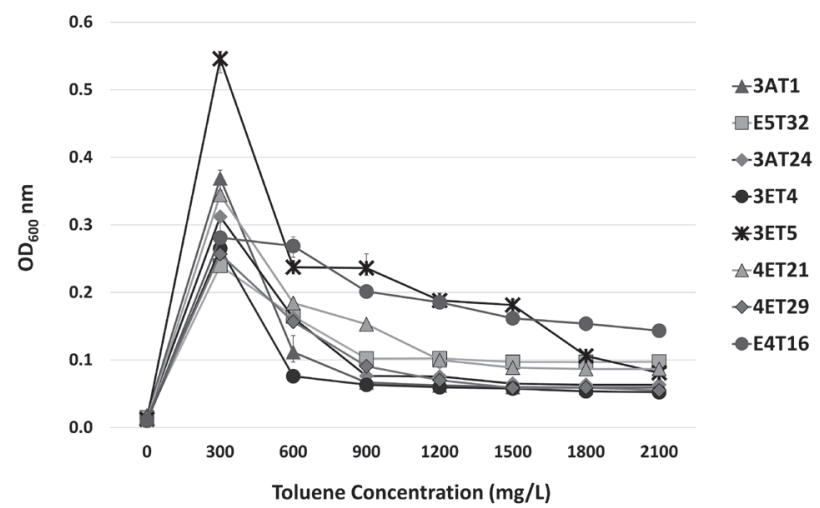

Fig. 2. Effect of toluene concentration on specific growth rate of bacterial strains after incubation at $37^{\circ} \mathrm{C}$ for 24 hours. otitidis) showed only growth in $300 \mathrm{mg} / \mathrm{l}^{-1}$ toluene. Other isolates showed moderate results. Increasing toluene concentration negatively affects biodegradation by making toxic effects on some bacterial cells [52]. However, there were also bacteria that grow at very high concentrations of toluene. Isolates 3ET5 (Streptococcus mitis) and 4ET21 (Stenotrophomonas acidaminiphila) tolerated toluene concentration up to $1500 \mathrm{mg} / \mathrm{l}^{-1}$. E4T16 (Pseudomonas balearica) showed growth up to $2100 \mathrm{mg} / \mathrm{l}^{-1}$ toluene. Compared to the literature, these isolates can tolerate extremely high concentrations. The examined bacterial species showed varying degrees of toluene degradability. For example, Acinetobacter junii was able to degrade 69,73 and $80 \%$ of 150,100 , and $50 \mathrm{ppm}$ toluene, respectively, within $72 \mathrm{~h}$ at $37^{\circ} \mathrm{C}$ [36]. In another study, it was concluded that three bacteria, Pseudomonas aeruginosa TJB01, Pseudomonas sp. TJB05 and Acinetobacter sp. SBG05 isolated from ferry dock water contaminated with toluene. $P$. aeruginosa TJB01 produced a higher toluene degradation with an initial concentration of $173.10 \mathrm{ppm}$ of toluene [33].

For determination of the toluene monooxygenase gene, the products obtained after PCRs made with toluene monooxygenase gene targeted primers were carried out on $1 \%$ agarose gels. The presence of toluene monooxygenase gene was determined by the presence of 466 bp product. Toluene monooxygenase-specific PCR was established for 48 isolates with positive results in municipal wastewater treatment plant and 
only 2 positive results were obtained. The specific PCR of toluene monoxygenase gene was established in 61 isolates from industrial waste water treatment plant with positive results and only 5 positive results were obtained. The number of isolates containing the toluene monooxygenase gene is very small. This is because the isolates have different mechanisms and genes for using or degrading toluene.

Previous studies have reported that toluenedegrading bacteria play an important role in degradation

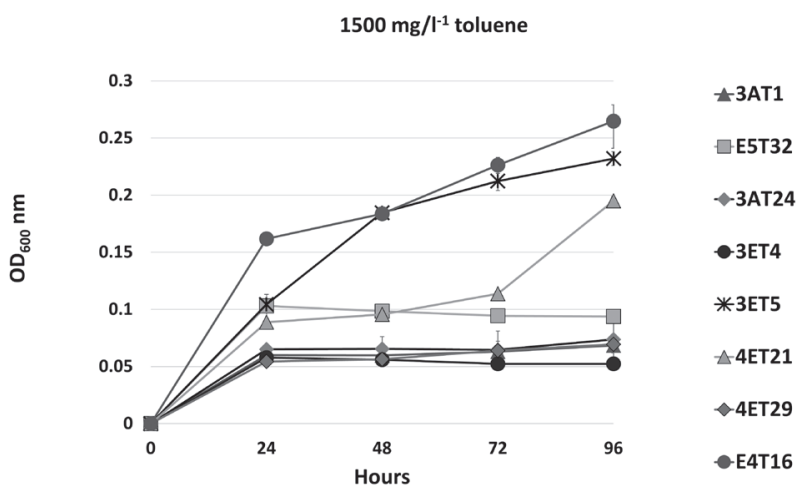

Fig. 3. Isolates' growth curve in $1500 \mathrm{mg} / \mathrm{l}^{-1}$ toluene concentration as a carbon resource.

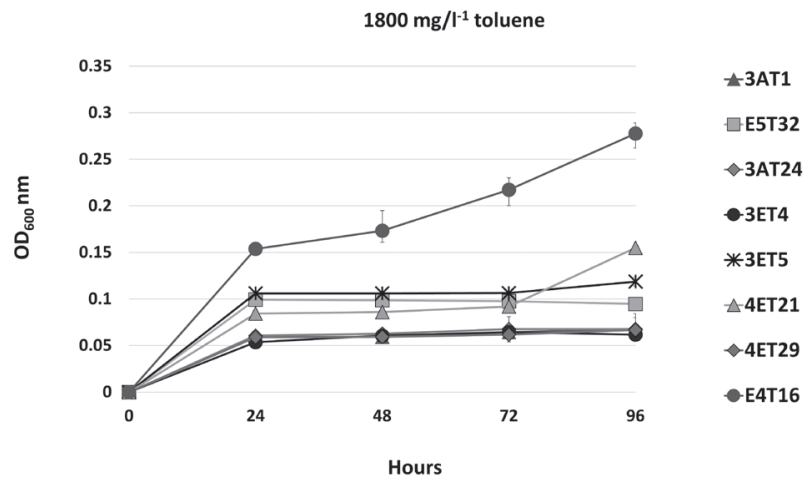

Fig. 4. Isolates' growth curve in $1800 \mathrm{mg} / \mathrm{l}^{-1}$ toluene concentration as a carbon resource.

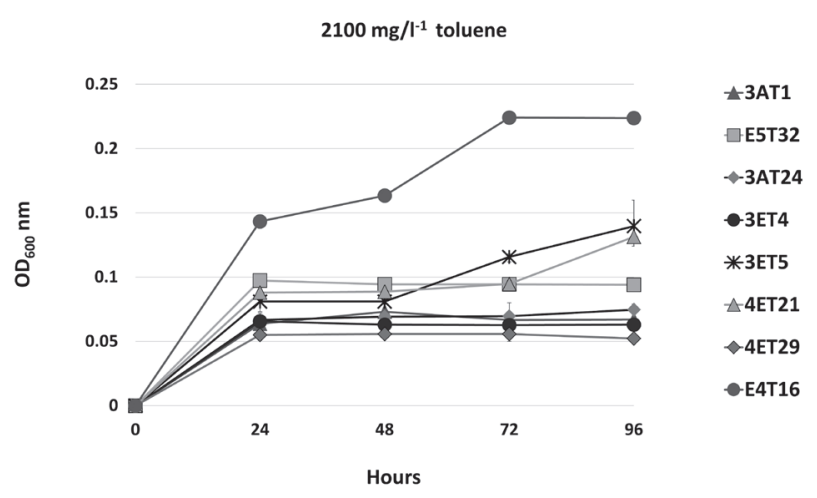

Fig. 5. Isolates' growth curve in $2100 \mathrm{mg} / \mathrm{l}^{-1}$ toluene concentration as a carbon resource.
Table 4. Results of benzene, ethyl benzene,xylene and phenol degradation of toluene degrading bacteria (Growth rate was shown by the symbols "+", "++, “+++"and "++++". The symbols were designed to compare both chemicals and bacteria with each other).

\begin{tabular}{|c|c|c|c|c|}
\hline $\begin{array}{c}\text { Strain } \\
\text { number }\end{array}$ & Benzene & $\begin{array}{c}\text { Ethyl } \\
\text { benzene }\end{array}$ & Xylene & Phenol \\
\hline 4ET21 & +++ & ++ & + & +++ \\
\hline 4ET29 & +++ & +++ & ++ & +++ \\
\hline 3AT1 & + & +++ & ++ & - \\
\hline 3AT24 & ++++ & +++ & ++++ & ++++ \\
\hline 3ET4 & +++ & +++ & + & +++ \\
\hline 3ET5 & +++ & +++ & ++ & +++ \\
\hline E4T16 & ++++ & ++++ & ++++ & ++++ \\
\hline E5T32 & ++++ & +++ & ++++ & ++++ \\
\hline
\end{tabular}

of BTEX compounds in nature. Hydrocarbondegrading microorganisms can be found many different environments. Among microorganisms, bacteria have been reported as common in hydrocarbon degradation [53]. For example, Acinetobacter, Pseudomonas, Gordonia, Rhodococcus, Cobetia, Halomonas, Alcanivorax, Marinobacter, Microbacterium, Corynebacterium, Ochrobactrum, Stenotrophomonas and Hahella [53-57]. In addition to potential for use in biological treatment of toluene removal, our bacteria can also be involved in the treatment of different substances such as benzene, toluene, xylene and phenol and in different processes as like enzymatic activities. So we tested BTEX degredation and enzyme production potentials of toluene degrading bacteria with simple methods. Bacterial isolates 4ET16 (Pseudomonas balearica), E5T32 (Stenotrophomonas sp.), 3AT24 (Acinetobacter baumannii), 4ET29 (Stenotrophomonas acidaminiphila) and 3ET5 (Streptococcus mitis) showed

Table 5. Level of enzyme activity for toluene degrading bacteria (Activity was scored by the symbols "+", "++" and "+++". These symbols showed the level of halos.).

\begin{tabular}{|c|c|c|c|c|c|}
\hline $\begin{array}{c}\text { Strain } \\
\text { number }\end{array}$ & Lipase & Protease & Amylase & $\begin{array}{c}\text { Car- } \\
\text { boxymeth- } \\
\text { ylcelullase }\end{array}$ & DNAase \\
\hline 4ET21 & + & ++ & - & - & ++ \\
\hline 4ET29 & + & +++ & - & - & +++ \\
\hline 3AT1 & + & ++ & - & + & ++ \\
\hline 3AT24 & - & - & + & + & - \\
\hline 3ET4 & + & ++ & - & - & ++ \\
\hline 3ET5 & ++ & - & - & - & ++ \\
\hline E4T16 & +++ & - & - & ++ & - \\
\hline E5T32 & + & - & + & - & - \\
\hline
\end{tabular}


Table 6. Toluene-degrading bacteria and isolation sources.

\begin{tabular}{|c|c|c|}
\hline Isolation Source & Species & References \\
\hline Contaminated sea water & Bacillus amyloliquefaciens, Sporosarcina halophile, Bacillus firmus & {$[46]$} \\
\hline $\begin{array}{c}\text { Soil sample from area contaminated } \\
\text { with petroleum products }\end{array}$ & $\begin{array}{c}\text { Baciluus badius } \\
\text { Brevibacterium liguefaciens } \\
\text { Pseudomonas mendonica } \\
\text { Pseudoxanthomonas mexicana }\end{array}$ & {$[47]$} \\
\hline $\begin{array}{c}\text { Surface sediment from oil contaminated area } \\
\text { paint areas }\end{array}$ & Bacillus cereus, Micrococcus spp, Pseudomonas aeruginosa E. coli, & {$[48]$} \\
\hline $\begin{array}{c}\text { Sample of soil in automobile repair and spray } \\
\text { Different contaminated soil from the Caspian Sea } \\
\text { (Bandar-Anzali, Guilan, Iran). }\end{array}$ & $\begin{array}{c}\text { Lysinibacillus boronitolerans, Bacillus subtilis, } \\
\text { Rhodococcus pyridinivorans, Acinetobacter schindleri }\end{array}$ & {$[49]$} \\
\hline $\begin{array}{c}\text { Ferry dock water contaminated with toluene } \\
\text { Soil, mud, river sediment, and sewage sludge } \\
\text { samples }\end{array}$ & Pseudomonas aeruginosa, Pseudomonas sp., Acinetobacter sp. & {$[33]$} \\
\hline
\end{tabular}

grown in BTEX media. Most of isolates showed growth in $300 \mathrm{mg} / \mathrm{l}^{-1}$ concentrations of each chemicals. 4ET16, E5T32 and 3AT24 growth rate was high in each hydrocarbon. 3ET4 and 4ET21 showed weakly growth in xylene and 3AT1 showed same result in benzene and there is no growth in phenol as seen in Table 4. In particular, members of the genus Pseudomonas have a wide variety of metabolisms that can survive in different environments and exhibit different features [58]. There were some studies for BTEX degradation. Twenty-three hydrocarbon-degrading bacteria strains were isolated from contaminated groundwater located in the Southern Amazon, Brazil. The amplification and sequencing of the $16 \mathrm{~S}$ rRNA gene showed that isolates belonged to the genus Bacillus [59]. In a study Bacillus pumilus MVSV3 was isolated from petroleum contaminated soil is utilized for BTEX degradation. At optimized conditions the isolate degraded $150 \mathrm{mg} / \mathrm{L}$ of BTEX completely within $48 \mathrm{~h}$ [35]. Also, Bujang et al. revealed in their study the Bacillus species have for high degradation capacity (up to $90 \%$ ) of total hydrocarbons in oily wastewater [60]. This is somewhat similar to our results, hydrocarbon-degrading bacteria have been characterized in two different soil. Bacterial

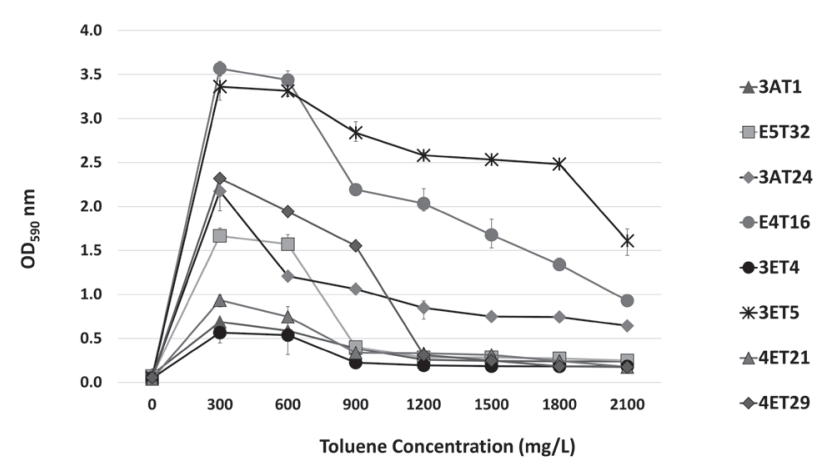

Fig. 6. Effect of toluene concentration on biofilm formation by bacterial strains in microtiter plates for 96 hours. populations were exposed to the hydrocarbon substrate by the addition of toluene concentrations, ranging from $0.5 \%$ to $10 \% \mathrm{~V} / \mathrm{W}$ and incubated. $16 \mathrm{~S}$ rRNA analysis of the isolates revealed that some of them were members of the genera Bacillus, Exiguobacterium, Enterobacter, Pseudomonas and Stenotrophomonas [15].

When enzymatic activity results were examined, Table 5 highlights the isolates that could be considered as potential producers due to their apparent halos. Several strains showed good production of amylase, DNase and lipase. Most of isolates showed lipase, DNase and protease activity. 4ET21, 4ET29, 3AT1 had both three of enzymes activity. E4T16 had high lipase and cellulose activity.

Although there are many studies on characterization of bacterial biofilms growing in a wide variety of environments, there is still little information about bacterial biofilms developed under hydrocarbon contaminated conditions. For this reason, in addition to BTEX degradation and enzyme production ability, determination of biofilm formation features' of isolates were aimed in our study. Examination of biofilm formation at different toluene concentrations at the end of the 96 hours incubation revealed that isolates E4T16, 3ET5 and 4ET29 had highly biofilm production potential. Strongest biofilm formation was observed E4T16 and 3ET5 as seen in Fig. 6. Biofilm is preferred as a natural, economical and easy method to eliminate toxic chemicals [61]. Microorganisms can tolerate adverse conditions such as exposure to toxic chemicals so biofilm formation can serve as a tool for the design of new systems for municipal and industrial wastewater. There are many reports about biofilm production abilities of Pseudomonas on various surface types [62-64]. But, the studies and reports for E4T16 (Pseudomonas balearica) 3ET5 (Streptococcus mitis) and 4ET29 (Stenotrophomonas acidaminiphila) which were determined to produce high potential biofilms in our study, is very low. 


\section{Conclusions}

The results presented here may be useful for the design and development of new processes technologies in wastewater treatment. In our study, isolates were identified as belong to Stenotrophomonas species Acinetobacter baumanni and Pseudomanas species with molecular methods. Most of isolates had benzene, ethyl benzene, xylene and phenol degradation, amylase, DNase and lipase production and biofilm formation potentials. Especially for E4T16 (Pseudomonas balearica) and 3ET5 (Streptococcus mitis) by applying our datas and knowledge of the bacterial biotechnological potential on degradation, enzyme production and biofilm formation, new systems for the degradation of municipal and industrial wastewater could be designed.

\section{Acknowledgements}

The author is grateful to Professor Doctor Mehmet Burçin MUTLU for his help and support.

\section{Conflict of Interest}

There is no conflict of interest.

\section{References}

1. BELLER H.R., SPORMANN A.M., SHARMA P.K., COLE J.R., REINHARD M. Isolation and characterization of a novel toluene-degrading, sulfatereducing bacterium. Appl. Environ. Microbiol. 62 (4), $1188,1996$.

2. WITZIG R., JUNCA H., HECHT H.H., PIEPER D.H. Assessment of toluene/biphenyl dioxygenase gene diversity in benzene-polluted soils: links between benzene biodegradation and genes similar to those encoding isopropyl benzene dioxygenases. Appl. Environ. Microbiol. 72 (5), 3504, 2006.

3. YOUNG L. Anaerobic Degradation of Aromatic Compounds In: GIBSON D., Microbial Degradation of Aromatic Compounds, Marcel Dekker Inc., New York, 1985.

4. MAIER R. Microorganisms and Organic Pollutants In: MAIER R., PEPPER I. and GERBA C., Environmental Microbiology, Academic Press, New York, 1999.

5. MUNOZ R., DIAZ L.F., BORDEL S., VILLAVERDE S. Inhibitory effects of catechol accumulation on benzene biodegradation in Pseudomonas putida F1 cultures. Chemosphere. 68 (2), 244, 2007.

6. EL-NAAS M.H., ACIO J.A., EL TELIB A.E. Aerobic biodegradation of BTEX: Progresses and Prospects. J. Environ. Chem. Eng. 2 (2), 1104, 2014.

7. PARALES R.E., PARALES J.V., PELLETIER D.A. DITTY J.L. Diversity of microbial toluene degradation pathways. Adv. Appl. Microbiol. 64, 1, 2008.

8. HANSON J.R., MACALADY J.L., HARRIS D., SCOW K.M. Linking toluene degradation with specific microbial populations in soil. Appl. Environ. Microbiol. 65 (12), 5403, 1999.

9. ALLEN J., COOMBS M. Covalent Binding of Polycyclic Aromatic Compounds to Mitochondrial and Nuclear DNA. Nature. 287 (5779), 244, 1980.

10. FILLEY C., HALLIDAY W., KLEINSCHMIDTDEMASTERS B. The Effects of Toluene on the Central Nervous System. J. Neuropathol. Exp. Neurol. 63, 1, 2004.

11. ZHANG L., ZHANG C., CHENG Z., YAO Y., CHEN J. Biodegradation of benzene, toluene, ethylbenzene, and $\mathrm{o}$-xylene by the bacterium Mycobacterium cosmeticum byf-4. Chemosphere. 90 (4), 1340, 2013.

12. SONG Y., JIANG B., TIAN S., TANG H., LIU Z., LI C., JIA J., HUANG W.E., ZHANG X., LI G. A whole-cell bioreporter approach for the genotoxicity assessment of bioavailability of toxic compounds in contaminated soil in China. Environ. Pollut. 195, 178, 2014.

13. ZYLSTRA G.J., GIBSON D.T. Toluene degradation by Pseudomonas putida F1. Nucleotide sequence of the todC1C2BADE genes and their expression in Escherichia coli. J. Biol. Chem. 264 (25), 14940, 1989.

14. SALLEH A.B., GHAZALI F.M., RAHMAN RNZA., BASRI, M. Bioremediation of Petroleum Hydrocarbon Pollution. Indian J. Biotechnol. 2, 41, 2003.

15. OLAPADE O., RONK A., Isolation, Characterization and Community Diversity of Indogenous Putative TolueneDegrading Bacterial Populations with Catechol-2,3dioxygenase Genes in Contaminated Soil. Microb. Ecol. 69 (1), 59, 2015.

16. BOLL M., FUCHS G., HEIDER J. Anaerobic oxidation of aromatic compounds and hydrocarbons. Curr. Opin. Chem. Biol. 6 (5), 604, 2002.

17. ALI S., FERNANDEZ-LAFUENTE R., COWAN D.A. Meta-pathway degradation of phenolics by thermophilic Bacilli. Enzyme Microb.Technol. 23 (7-8), 462, 1998.

18. CİFUENTES A., ANTÓN J., BENLLOCH S., DONNELLY A., HERBERT R.A. RODRÍGUEZVALERA F. Prokaryotic diversity in Zostera noltiicolonized marine sediments. Appl. Environ. Microbiol. 66 (4), 1715, 2000.

19. NOGALES B., MOORE E.R., ABRAHAM W.R., TIMMIS K.N. Identification of the metabolically active members of a Bacterial community in a polychlorinated biphenyl-polluted moorland soil. Environ. Microbiol. 1 (3), 199, 1999.

20. SINGKA D., KUMDHITIAHUTSAWAKUL L., REKKRIANGKRAI P., PATHOM-AREE W. A simple method for DNA extraction from activated sludge. Chiang Mai J. Sci. 39 (1), 111, 2012.

21. LANE D.J., PACE B., OLSEN G.J., STAHL D.A., SOGIN M.L., PACE N.R. Rapid determination of 16S ribosomal RNA sequences for phylogenetic analyses. Proc. Natl. Acad. Sci. 82 (20), 6955, 1985.

22. VANEECHOUTTE M., ROSSAU R., VOS P.D., GILLIS M. Rapid identification of bacteria of the Comamonadaceae with amplified ribosomal DNA-restriction analysis (ARDRA). FEMS Microbiol. Lett. 93, 227, 1992.

23. JUKES T.H., CANTOR C.R. Evolution of protein molecules. In Munro HN, editor, Mammalian Protein Metabolism, pp. 21-132, Academic Press, New York, 1969.

24. KUMAR S., STECHER G., LI M., KNYAZ C., TAMURA K. MEGA X: Molecular Evolutionary Genetics Analysis across computing platforms. Mol. Biol. Evol. 35, 1547, 2018. 
25. FELSENSTEIN J. Confidence limits on phylogenies: An approach using the bootstrap. Evolution. 39, 783, 1985.

26. BALDWIN B.R., NAKATSU C.H., NIES L. Detection and enumeration of aromatic oxygenase genes by multiplex and real-time PCR. Appl. Environ. Microbiol. 69 (6), 3350, 2003.

27. SONUNE N., GARODE A. Isolation, characterization and identification of extracellular enzyme producer Bacillus licheniformis from municipal wastewater and evaluation of their biodegradability. Biotechnology Research and Innovation. 2 (1), 37, 2018.

28. CAPPUCCINO J.G., SHERMAN N. Microbiology: a laboratory manual. (San Francisco: Pearson/Benjamin Cummings), 2005.

29. JUNCA H., PIEPER D.H. Amplified functional DNA restriction analysis to determine catechol 2,3-dioxygenease gene diversity in soil bacteria. J. Microbiol. Methods. 55, 697, 2003.

30. DJORDJEVIC D., WIEDMANN M., MCLANDSBOROUGH L.A. Microtiter plate assay for assessment of Listeria monocytogenes biofilm formation. Appl. Environ. Microbiol. 68, 2950, 2002.

31. GITI E., MEHDI H., NASSER G. Development of a microtitre plate method for determination of phenol utilization, biofilm formation and respiratory activity by environmental bacterial isolates. Int. Biodeterior. Biodegradation. 56 (4), 231, 2005.

32. SANTISI S., CAPPELLO S., CATALFAMO M., MANCINI G., HASSANSHAHIAN M., GENOVESE L., GIULIANO L., YAKIMOV M.M. Biodegradation of crude oil by individual bacterial strains and a mixed bacterial consortium. Braz. J. Microbiol. 46 (2), 377, 2015.

33. LESTARI W., PRIYANI N., MUNIR E., HARTANTO A., WARSITO K. Toluene-degrading activity of local bacteria isolated from contaminated sea of North Sumatera. In IOP Conference Series: Earth and Environmental Science. 348 (1), 012047, 2019.

34. JINDROVA, E., CHOCOVA, M., DEMNEROVA K., BRENNER,V. Bacterial aerobic degradation of benzene, toluene, ethylbenzene and Xylene. Folia Microbiol. 47, 83, 2002.

35. SURENDRA S.V., MAHALINGAM B.L., VELAN M. Degradation of monoaromatics by Bacillus pumilus MVSV3. Braz. Arch. Biol. Technol. 60, 1, 2017.

36. SINGH P., SINGH V.K., SINGH R., BORTHAKUR A., KUMAR A., TIWARY D., MISHRA P.K. Biological degradation of toluene by indigenous bacteria Acinetobacter junii $\mathrm{CH005}$ isolated from petroleum contaminated sites in India. Energ. Ecol. Environ. 3 (3), $162,2018$.

37. MEN J., CHENG F., Biodegradation and growth characteristics of a toluene-degrading strain. Afr. J. Biotechnol. 10 (61), 13299, 2011.

38. SHAMSI N., MORAVEJ R. Isolation and identification of toluene-degrading bacteria from oil spills of Gharehsoo River located in Kermanshah city. JMV, (Journal Of Microbial World). 9 (2) 27, 156, 2016.

39. MUCCEE F., EJAZ S. Biochemical, molecular and antibiotic resistance profile of multi-potential toluene metabolizing bacteria isolated from tannery effluents. bioRxiv. 34024, 2018.

40. MANGWANI N., SHUKLA S.K., KUMARI S., RAO T.S., DAS S. Characterization of Stenotrophomonas acidaminiphila NCW-702 biofilm for implication in the degradation of polycyclic aromatic hydrocarbons. J. Appl. Microbiol. 117 (4), 1012, 2014.
41. CERQUeIRA V.S., HOLLENBACH E.B., MABONI F., CAMARGO F.A., MARIA DO CARMO R.P., BENTO F.M. Bioprospection and selection of bacteria isolated from environments contaminated with petrochemical residues for application in bioremediation. World J. Microbiol. Biotechnol. 28 (3), 1203, 2012.

42. BENNASAR A., ROSSELLO-MORA R., LALUCAT J., MOORE E.R. 16S rRNA Gene Sequence Analysis Relative to Genomovars of Pseudomonas stutzeri and Proposal of Pseudomonas balearica sp. nov. Int. J. Syst. Evol. Microbiol. 46 (1), 200, 1996.

43. YETTI E., THONTOWI A., LISDIYANTI P. Screening of Marine Bacteria Capable of Degrading Various Polyaromatic Hydrocarbons. Squalen Bulletin of Marine and Fisheries Postharvest and Biotechnology. 10 (3), 121, 2015.

44. VAN GESTEL K., MERGAERT J., SWINGS J., COOSEMANS J., RYCKEBOER J. Bioremediation of diesel oil-contaminated soil by composting with biowaste. Environ Pollut. 125 (3), 361, 2003.

45. SINGH P., TIWARY B.N. Isolation and characterization of glycolipid biosurfactant produced by a Pseudomonas otitidis strain isolated from Chirimiri coal mines, India. Bioresour. Bioprocess. 3 (1), 42, 2016.

46. AFROUZOSSADAT H.A., EMTIAZI G., GHASEMI S.M. The role of exopolysaccharide, biosurfactant and peroxidase enzymes on toluene degradation by bacteria isolated from marine and wastewater environments. Jundishapur J. Microbiol. 5, 479, 2012.

47. KHANDEKAR S., DEWALIYA V., TRIVEDI N.D., TRIVEDI U.N. Isolation and identification of toluene degrading microbes and detection of catabolic genes. American Journal of Biochemistry and Molecular Biology. 4, 42, 2014

48. JAYANTHI R., HEMASHENPAGAM N, Isolation and identification of petroleum hydrocarbon degrading bacteria from oil contaminated soil samples. IJNTPS. 5, $102,2015$.

49. JACOB J.H., IRSHAID F.I. Toluene Biodegradation by Novel Bacteria Isolated from Polluted Soil Surrounding Car Body Repair and Spray Painting Workshops. J. Environ. Prot. 6, 1417, 2015.

50. HEYDARNEZHAD F. HOODAJI M., SHAHRIARINOUR M., TAHMOURESPOUR A., SHARIATI S. Optimizing Toluene Degradation by Bacterial Strain Isolated from Oil-Polluted Soils. Pol. J. Environ. Stud. 27, 655, 2018.

51. NGUYEN O.T., HA D.D. Degradation of chlorotoluenes and chlorobenzenes by the dual-species biofilm of Comamonas testosteroni strain KT5 and Bacillus subtilis strain DKT. Ann. Microbiol. 69, 267, 2019.

52. DORER C., VOGT C., NEU T.R., STRYHANYUK, H., RICHNOW H.H. Characterization of toluene and ethylbenzene biodegradation under nitrate-, iron (III)and manganese (IV)-reducing conditions by compoundspecific isotope analysis. Environ. Pollut. 211, 271, 2016.

53. VARJANI S.J., UPASANI V.N. Biodegradation of petroleum hydrocarbons by oleophilic strain of Pseudomonas aeruginosa NCIM 5514. Bioresour. Technol. 222, 195, 2016.

54. MORAIS E.B., TAUK-TORNISIELO S.M. Biodegradation of oil refinery residues using mixed-culture of microorganisms isolated from a landfarming. Braz. Arch. Biol. Technol. 52 (6), 1571, 2009.

55. HASSANSHAHIAN M., EMTIAZI G., CAPPELLO S. Isolation and characterization of crude-oil-degrading 
bacteria from the Persian Gulf and the Caspian Sea. Mar. Pollut. Bull. 64 (1), 7, 2012.

56. HASSANSHAHIAN M., ZEYNALIPOUR M.S., MUSA F.H. Isolation and characterization of crude oil degrading bacteria from the Persian Gulf (Khorramshahr Provenance). Mar. Pollut. Bull. 82 (1-2), 39, 2014.

57. ABED R.M.M., AL-SABAHI J., AL-MAQRASHI F., AL-HABSI A., AL-HINAI M. Characterization of hydrocarbon-degrading bacteria isolated from oilcontaminated sediments in the Sultanate of Oman and evaluation of bioaugmentation and biostimulation approaches in microcosm experiments. Int. Biodeterior. Biodegradation. 89, 58, 2014.

58. HE W.H., WANG Y.N., DU X., ZHOU Y., JIA B., BIAN J., LIU S.J., CHEN G.C. Pseudomonas linyingensis sp. nov.: a novel bacterium isolated from wheat soil subjected to long-term herbicides application. Curr. Microbiol. 65 (5), 595, 2012.

59. LIMA S.D., OLIVEIRA A.F., GOLIN R., LOPES V.C.P., CAIXETA D.S., LIMA Z.M., MORAIS E.B. Isolation and characterization of hydrocarbon-degrading bacteria from gas station leaking-contaminated groundwater in the
Southern Amazon. Brazil. Braz. J. Biol. Epub August 05, 2019.

60. MARINA B., NOOR A.I., AWENG E.R. Biodegradation of oily wastewater by pure culture of Bacillus cereus. J. Agric. Biol .Sci. 8 (2), 108, 2013.

61. ELIAS S., BANIN E. Multi-species biofilms: living with friendly neighbors. FEMS Microbiol. Rev. 36, 990, 2012.

62. MASÁK J., ČEJKOVÁ A., SCHREIBEROVÁ O., REEZANKA T. Pseudomonas biofilms: possibilities of their control. FEMS Microbiol. Ecol. 89, 1, 2014.

63. RASAMIRAVAKA T., LABTANI Q., DUEZ P., EL JAZIRI M. The formation of biofilms by Pseudomonas aeruginosa: a review of the natural and synthetic compounds interfering with control mechanisms. Biomed. Res. Int. 759348, 2015.

64. BENEDEK T., SZENTGYÖRGYI F., SZABÓ I., KRISZT B., RÉVÉSZ F., RADÓ J., MARÓTI G., TÁNCSICS A. Aerobic and oxygen-limited enrichment of BTEXdegrading biofilm bacteria: dominance of Malikia versus Acidovorax species. Environ. Sci. Pollut. Res. 25 (32), 32178, 2018. 
